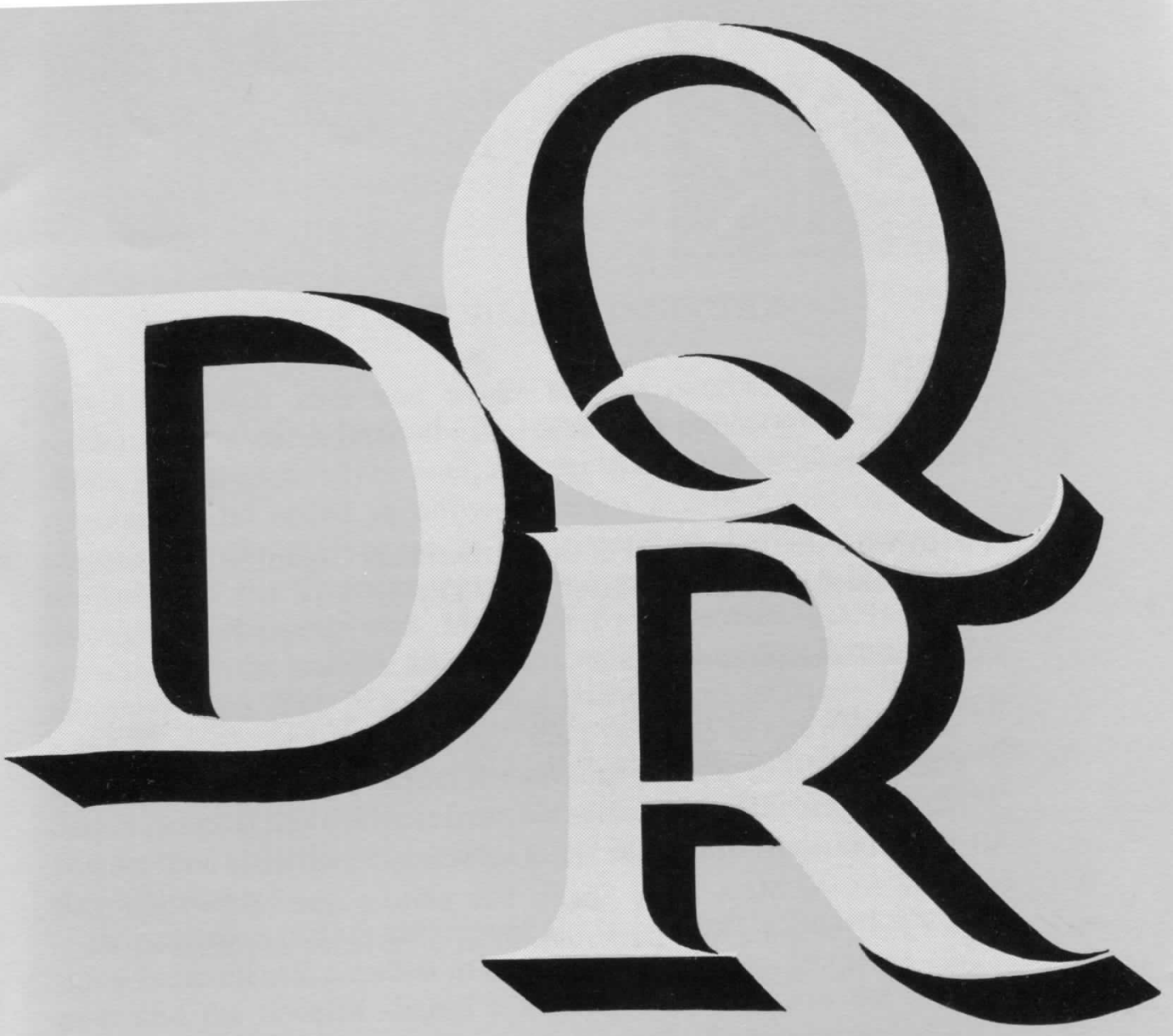

Dutch Quarterly Review of Anglo- American fetters
Volume 17,1987 / 3
Rodopi 


\section{THE FROST-MELVILLE CONNECTION}

Ostensibly, their lives and works suggest contrast more than resemblance: a world-famous writer of densely philosophical novels versus a plain-spoken lyric poet; a career that began with best-seller popularity and ended in oblivion versus a career that did the opposite; a life that began a half-generation before Emerson promulgated the Transcendentalist movement versus a life that (though overlapping with Melville's for seventeen years) was crowned with the laureate honors bestowed by President Kennedy's administration. Yet, in a letter to a friend Frost insisted: "I was brought up on Melville... Don't dare to set up to like him better than I like him". ${ }^{1}$ And across the seventy-years breadth of Frost's career as a poet, the evidence from his verse irresistibly bears out the two writers' affinities, whose final effect is to place Frost as a latter day Melvillean.

Beneath their surface differences, the two writers' affinities rested upon fundamental parallels in theme and technique. In theme, the poet and the novelist shared a lifelong fixation upon the most significant issue in Western literature since the Romantic period that Crisis of Belief, or search for beliefs to live (and die) by, which has undergirded our greatest works from In Memoriam and The Brothers Karamazov to and beyond The Waste Land. In technique, the two writers bear out Nabokov's view that "the bamboo bridge" linking poetry and prose is the metaphor. For his part, Robert Frost asserted that "Poetry is simply made of metaphor ... Every poem is a new metaphor inside it is nothing". ${ }^{2}$ And though Melville did not theorize explicitly about metaphor, his works depend largely

1. Letter of RF to John Freeman, c. November 5, 1925. Cited in Elaine Barry, Robert Frost on Writing (New Brunswick, New Jersey: 1973), p. 81.

2. Robert Frost, "The Constant Symbol" (1946). See Robert Frost: Poetry and Prose, eds Connery Lathem and Lawrance Thompson (New York: Holt, Rinehart and Winston, 1972), p. 401. 
upon a richly metaphorical imagination for rendering his thematic insights.

Among the numerous passages underscoring the two writers' affinity regarding the Crisis of Belief, several offer themselves at once to comparative analysis. For both artists this ground theme originated in an awareness of mortality toward which they adopted an agnostic position. "There may be much or little beyond the grave", Frost says, "But the strong are saying nothing until they see" ("The Strong Are Saying Nothing"). ${ }^{3}$ Melville's version of this sentiment may be seen variously in Stubb's view of death as "a sort of call of the watch to tumble aloft ... about something which he would find out when he obeyed the order, and not sooner" (MobyDick, Chapter 27), or in Father Mapple's closing prayer (Chapter 9): "I leave eternity to Thee; for what is man that he should live out the lifetime of his God?",

For both artists, the final response to the Crisis of Belief was to honour the stance of the seeker. In "The Lee Shore" (Chapter 23 of Moby-Dick) and in "Neither Out Far Nor In Deep", both artists portray the human attraction toward the open sea as proof of the truth-seeking mind. "The people along the sand/All turn and look one way", Frost declares in the latter poem; "They turn their back on the land./They look at the sea all day". The futility of this truth-hunger, in Frost's view, does not matter: "They cannot look out far./They cannot look in deep./But when was that ever a bar/To any watch they keep?"' (Poetry, p.301). In Melville's version of this sea-land metaphor, the land represents the safety of fixed certitudes - "in the port is safety, comfort, hearthsone... all that's kind to our mortalities" - yet the dangers of the sea are preferred: "all deep earnest thinking is but the intrepid effort of the soul to keep the open independence of her sea" (Moby-Dick, p. 97).

Frost's sea-starers would presumably agree with Melville's

3. The Poetry of Robert Frost, ed. Connery Lathem (New York: Holt, Rinehart and Winston, 1969), p. 300. To economize on footnoting, I shall herafter cite page references to this book within my main text.

4. Herman Melville, Moby-Dick, Norton Critical Edition (New York: W.W. Norton and Company 1967), pp. 105, 51. Because so many editions of this novel are in currency, I shall cite chapter references within my main text, along with page references to this edition. 
contention that "in landlessness alone resides the highest truth", thereby endorsing the lack of certitudes to live by. In keeping their own independence of intellect, both Frost and Melville attempted to reconceptualize two pillars of American culture: the Bible and the Transcendentalist movement. Melville's use of the Bible focused primarily on the New Testament, as witnessed in the conversion of the philosopher Babbalanja from despair to worship of Alma (Christ) in Mardi, and later in the symbolic rendering of the Gospels in Billy Budd. Frost's Biblical interest fastened mainly on the Old Testament, as he proved in his most ambitious poem, A Masque of Reason (to which all his other poems are footnotes, he once remarked), where he used Job as his persona. ("Here endeth chapter forty-three of Job", this poetic drama ends; the Book of Job in the Bible has forty-two chapters.)

Regarding the Transcendentalist movement, too, both writers owed a substantial debt to the greatest of the Transcendentalist prophets, Ralph Waldo Emerson. Emerson's two central themes his belief in "the infinitude of the private man" and his intuition that "behind nature, throughout nature, spirit is present - are embodied in Captain Ahab, though to negative conclusions: for all his Transcendental willfulness, he is crushed like a flea; and, for Ahab, the spirit behind nature is evil ("the intangible malignity" is the phrase Ishmael uses). ${ }^{5}$ Frost's sense of Emerson, fixing upon the latter's poems more than his esays, was more positive. "Somewhere in there I had a great time with Emerson", he said of his early encounter with Emerson's poetry; and in A Masque of Reason he rendered an extraordinary tribute in calling Emerson's Uriel "the greatest Western poem yet"6 (pace Dante, Goethe, and Milton!). Melville, always conscious of the ambiguity of things, would doubtless have assented to Frost's praise of Emerson's moral ambiguity in this poem, which says "Evil will bless and ice will burn". In addition, Frost saw a remarkable foreshadowing of Einstein's curvature of light in Emerson's argument against a

5. Moby-Dick, p. 160, and Ralph Waldo Emerson, "Nature", Part VII, in Selections from Ralph Waldo Emerson, ed. Stephen E. Whicher (Boston: Houghton Mifflin Co., Riverside Editions 1957), p. 50.

6. Robert Frost on Writing, p. 75, and Poetry, p. 485. 
(straight) line: "Line in nature is not found;/Unit and universe are round;/In vain produced, all rays return"?

This mention of Einstein points up yet another major affinity between Frost and Melville: for both writers, the Crisis of Belief was occasioned mainly by their readings in the leading contemporary science - geology in Melville's case, and physics in Frost's. In this regard, it is notable that Melville included among his "Extracts" in Moby-Dick (p. 11) a fragment from "Darwin's Voyage of a Naturalist" (The Origin of Species was nearly a decade in the future); a corresponding episode is the remark of an interviewer who, visiting Robert Frost's home, noted " a copy of Einstein's Theory of Relativity ... on the table". ${ }^{8}$ In Chapter 104 of Moby-Dick, Ishmael takes time out to "present my credentials as a geologist", in which role he mentions "Tertiary formations" and "Cetacean fossils" en route to a view of time and change quite at odds with the account of Creation in Genesis: "I obtain dim, shuddering glimpses into those polar eternities; when wedged bastions of ice pressed upon what are now the Tropics; and ... [the whale] left his wake along the present lines of the Andes and Himmalehs" (pp. 379-380). For Frost, the importance of modern physics lay in what has been called the most pessimistic idea ever conceived by the mind of man - entropy, the theory that because of the Second Law of Thermodynamics, the whole universe is doomed to become extinct as the suns and galaxies gradually burn out. Frost's most elaborate portayal of this process is in "West-running Brook" - whose title implies entropy in that the West has long represented the direction of death in literature. The brook is "The stream of everything that runs away... /To fill the abyss's void with emptiness"; it is "time, strength, tone, light, life, and love-/And even substance lapsing unsubstantial;/The universal cataract of death/ That spends to nothingness" (Poetry, p. 259).

7. These lines quoted from Emerson's "Uriel" elicited the following response in Frost's A Masque of Reason, ending in the concept of entropy "... how rays return upon themselves,/To quote the greatest Western poem yet./Though I hold rays deteriorate to nothing,/First white, then red, then ultra red, then out" (Poetry, p. 485).

8. Interviews with Robert Frost, ed. Connery Lathem (New York: Holt, Rinehart and Winston, 1966), p. 117. 
In their search for beliefs to live by, Frost and Melville proceeded in similar fashion to examine a spectrum of possibilities ranging from atheism to quasi-orthodoxy. Father Mapple's orthodox humility (cited earlier) finds its correlation in Frost's "A Prayer in Spring", which counsels - like Father Mapple - leaving eternity to God. Frost's prayer is to live in the moment without thought of death: "...give us not to think so far away/As the uncertain harvest; keep us here/All simply in the springing of the year". As Father Mapple had preached obedience to God, Frost advises the acceptance of one's life as a thing God consumes for unknowable purposes - "which it is reserved for God above/To sanctify to what far ends $\mathrm{He}$ will,/But which it only needs that we fulfill" (Poetry, p. 12).

At the opposite end of the theological spectrum, Frost and Melville likewise displayed close affinities in their atheist speculations. Chapter 42 of Moby-Dick, "On the Whiteness of the Whale", most clearly expounds this level of Melville's thinking. The color white "strikes more of panic to the soul than that redness which affrights in blood", Melville says, because it bespeaks (in the frozen lifelessness of the North Pole and in the inhuman immensity of the Milky Way) the "heartless voids" of Nature, and "thus stabs us from behind with the thought of annihilation". What makes it worse are the gaudy, vital colors with which Nature disguises this atheist vacancy at its center - the "tinges of sunset skies and woods; yea, and the gilded velvets of butterflies, and the butterfly cheeks of young girls... so that all deified Nature absolutely paints like the harlot, whose allurements cover nothing but the charnel-house within". Elsewhere in Moby-Dick Melville describes the "universal cannibalism of the sea" which is "treacherously hidden beneath the loveliest tints of azure" (Chapter 58). ${ }^{9}$

Within the brevity of a single sonnet, "Design", Robert Frost achieved a succint version of these sentiments. Here he too depicts whiteness as a perverse mask of evil inasmuch as a flower, a moth, and a spider (all of them white) have acted out the universal cannibalism of nature: "What had that flower to do with being

9. The three references to Moby-Dick in this paragraph relate to pages 164, 169-170, and 235. 
white?/ ... What but design of darkness to apall - /If design govern in a thing so small" (Poetry, p. 302). Even the spider's web contributes to a Melvillean sense of theodicy in this poem, in that its perfect geometry comprises a mockery of the eighteenth-century "argument from design" - the Deistic inference of a benevolent Providence from Newton's cosmic order.

Between their two extremes of orthodoxy and atheism, both Frost and Melville coped with their Crisis of Belief through recourse to a wider range of literary responses. Probably the most important of these were the stoic, and comic, and what was later defined as the existentialist position. In his poem "The Conflict of Convictions (1860-1861)", Melville used capital letters to underscore his stoic view of the agnostic dilemma: "YEA AND NAY_/EACH HATH HIS SAY;/BUT GOD HE KEEPS THE MIDDLE WAY .../ WISDOM IS VAIN AND PROPHESY". ${ }^{10}$ Frost, who said "Religion is merely consolation for what we don't know", framed the issue in a couplet: "We dance around in a ring and suppose,/But the Secret sits in the middle and knows". ${ }^{11}$ Elsewhere, in "Sitting by a Bush in Broad Sunlight", he ruefully records the failure of both adversaries in the Crisis of Belief - science and religion - to give men the answers they need: the sunlight (referring to the beginning of evolution) no longer creates life as Frost watches; and the bush (referring to God's speech to Moses) no longer announces God's presence. "God once spoke to people by name./The sun once imparted its flame", Frost concludes; "One impulse persists as our breath;/The other persists as our faith" (Poetry, p. 266).

With so frail a hold upon life and faith, it was natural that both men moved toward a comic response to the human predicament comic in the sense of black humour. The theistic dimensions of this attitude were expressed by Frost in a couplet - "Forgive, O Lord, my little jokes on Thee/And I'll forgive Thy great big one on me" (Poetry, p. 428) - and by Melville in Chapter 49 of Moby-Dick ("The Hyena"): "There are certain times and occasions in this

10. Herman Melville, Selected Tales \& Poems, ed. Richard Chase (New York: Holt, Rinehart and Winston, 1965), p. 382.

11. Introduction to King Jaspur. See Lathem and Thompson, p. 349. Also Poetry, p. 362. 
strange mixed affair we call life when a man takes this whole universe for a vast practical joke... And ... prospects of sudden disaster, peril of life and limb; all these, and death itself, seem to him only sly, good-natured hits, and jolly punches in the side bestowed by the unseen and unaccountable old joker" (p. 195). Stubb, Melville's chief embodiment of this mentality, maintains its integrity right up to the moment of his death, turning Starbuck's earnest last prayer - "My God, stand by me now!" - into a final quip: "Stand not by me, but stand under me ... ye assassins of as good a fellow as ever spouted up his ghost" (Chapter 135: "The Chase - Third Day," p. 467).

For Melville, this black humour approach eventually deepened into the perverse mockery of The Confidence Man, in which God Himself is at last disclosed as the title character: "And Jehovah shall be thy confidence," Melville cites from the Bible. ${ }^{12}$ For Frost, such excesses are curbed by a determination to "never ... let grief go further than it could in play ... Give us immedicable woes - woes that nothing can be done for - woes flat and final. And then to play. The play's the thing. Play's the thing."13 In his earlier work Herman Melville sometimes achieved this level of sophistication, as when (in Chapter 132 of Mardi) he envisioned the "geological sandwich," its bread being the strata of the earth's crust and its meat and "sundry greens" being the fossilized fauna and flora spread across those strata. ${ }^{14}$ Frost similarly made play of his deep fear of entropy in "It Bids Pretty Fair," whose metaphor for human life on earth is a long-running stage performance:

The play seems out for an almost infinite run.

Don't mind a little thing like the actors fighting.

The only thing I worry about is the sun.

We'll be all right if nothing goes wrong with the lighting.

(Poetry, p. 392)

12. Herman Melville, Selected Tales \& Poems, ed. Richard Chase (New York: W.W. Norton \& Company, 1971), p. 216.

13. Introduction to King Jasper. See Lathem and Thompson, pp. 350, 353.

14. Herman Melville, Mardi, Signet Classic Edition (New York: New American Library, 1964), pp. 346-347. 
In A Masque of Reason, the play's the thing in both senses - the work $i$ a play, in the mode of poetic drama, and it does make play of Frost's deepest philosophical anxieties. "The artist in me cries out for design," Frost's Job exclaims in this poem; God's reply is a black humorist's rationale: "Job and I together/Found out the discipline man needed most/Was to learn his submission to unreason" (Poetry, pp. 481-482). Examples of unreason abound in the poem, most notably in God's refusal to answer the crucial questions: "We don't know where we are, or who we are./We don't know one another; don't know you [God]/...[or] Whether there's any part of man immortal." (Poetry, p. 483). Herman Melville also used the Book of Job by way of completing Moby-Dick, whose epilogue cites Job's messenger: “And I only am escaped alone to tell thee." Essentially, Melville's Ishmael has also learned Job's "submission to unreason", giving his own version of Frost's "We dance around in a ring and suppose": "There is no steady unretracing progress in this life; we do not advance through fixed gradations, and at the last one pause: - through infancy's unconscious spell, boyhood's thoughtless faith, adolescence's doubt (the common doom), then scepticism, then disbelief, resting at last in manhood's pondering repose of If. But once gone through, we trace the round again; and are infants, boys, and men, and Ifs eternally" (Chapter 114, p. 406).

From their failed quest for meaning, Frost and Melville in the end derived a handful of precepts to live by - precepts so limited to actual personal experience as to reasonably merit the designation "existential". Like Kierkegaard and Camus (their respective contemporaries), Melville and Frost took the essential absurdity of life - especially in the face of death - as a starting-point, and then defined some values not related to any largerophilosophical systems. In his poetry, Frost explained this process as a movement that "begins in delight and ends in wisdom ..., in a clarification of life - not necessarily a great clarification, such as sects and cults are founded on, but in a momentary stay against confusion." 15 The "wisdom" thus attained was essentially self-knowledge; in poems

15. Robert Frost, "The Figure a Poem Makes" (1939). Included in Lathem and Thompson, p. 394. 
like "The Trial by Existence" and "Kitty Hawk" (published a half-century apart) Frost thus shared John Keats's view of life as "a value of soul-making." ${ }^{16}$ In A Masque of Reason, Job's wife defines this idea as the only meaning imaginable for man's life on Earth: "Except as a hard place to save his soul in,/A trial ground where he can try himself/And find out whether he is any good,/It would be meaningless" (Poetry, p. 484).

For Melville the experience-tested precepts to live by are those denoted by Ishmael's survival: the human bond with Queequeg (versus Ahab's Transcendental self-reliance); Job-like humility (versus Ahab's Promethean pride); pity for one's fellow creatures (versus the book's ubiquitous "heartlessness" of men and Nature); an abhorrence of malice (Ishmael is the only character to renounce "all ill-will, or petulance, or malice, of any kind whatsoever" Chapter 94, p. 348); and - perhaps most important - an openminded, searching intellect (versus Ahab's monomania). Frost's poems variously endorse these virtues, with perhaps greatest emphasis on honesty of intellect and the kind of humility that finds expression in humour. And both men seemed willing to die with the courage of their agnostic vision: five years after Moby-Dick, Melville told Hawthorne he had "pretty much made up his mind to be annihilated"; ${ }^{17}$ and Robert Frost, in the year of his death, made a stoical metaphor of his tree-chopping: "I see for Nature no defeat/In one tree's overthrow/Or for myself in my retreat/For yet another blow" ("In Winter in the Woods Alone," Poetry, p. 470).

Although space does not permit more than a checklist of further affinities, a few of the larger ones deserve closing mention: Melville's Burkean theme in Billy Budd - "With mankind ... forms, measured forms are everything" - vis-a-vis Frost's conservative temperament: "There is more religion outside church than in, more love outside marriage than in, more poetry outside verse than in... Yet I am an institutional kind of man"; ${ }^{18}$ Frost's poems of fall and

16. See, in any edition of Keats's letters, the entry to George and Georgiana Keats dated 21 April, 1819.

17. See the entry in Hawthorne's English Notebooks for November 20, 1856.

18. Melville, Selected Tales \& Poems, p. 371; and Lathem, Interviews, p. 249. 
The Fall, like "The Oven Bird" and "Nothing Gold can Stay", vis-a-vis Melville's versions of paradise lost and innocence ruined in "Jimmy Rose" and "The Fiddler" and "Benito Cereno"; Melville's sense of universal ambiguity, reaching even to the subtitle of Pierre (Or, the Ambiguities) vis-a-vis Frost's couplet, originally offered to the United Nations as a motto rejected by that body: "Nature within her inmost self divides/To trouble men with having to take sides" (Poetry, p. 468); Frost's theme of "the fear of Man - the fear that men won't understand us and we shall be cut off from them" vis-a-vis Melville's actual experience of alienation as an aging artist and his premonition of that state in "Bartleby the Scrivener"; ${ }^{19}$ and, to close with a metaphor, Melville's cosmic voyage at the end of White Jacket ("We mortals are all on board a fast-sailing, neversinking world-frigate, of which God was the shipwright; and she is but one craft in a Milky-Way fleet ... for ages and ages we continue to sail with sealed orders" ${ }^{20}$ vis-a-vis Frost's similar use of plane travel in "Kitty Hawk": "Westerners inherit/A design for living/ Deeper into matter ... Through our kiting ships/Prove but flying chips/... We have made a pass/At the infinite" (Poetry, p. 435).

Their affinities were not the only reason Robert Frost called Melville "one of America's splendors in art", ${ }^{21}$ yet we must say that such affinities sufficed to justify Frost's idea of art as the most perfect medium of communication. Postulating his thesis that "recognition in art is all", or that "correspondence is all", Frost rendered a lyrical prose statement of the concept: "Mind must convince mind that it can uncurl and wave the same filaments of subtlety, soul convince soul that it can give off the same shimmers of eternity." 22 The chronology of things made Frost's admiration of Melville unreciprocal; yet perhaps the foregoing argument may suffice to enclose Frost within a final, famous Melvillean metaphor. Of Frost as of Hawthorne our evidence attests, Melville might have

19. Introduction to King Jasper, cited in Lathem and Thompson, p. 347.

20. Herman Melville, White Jacket (New York: Holt, Rinehart and Winston, 1967), p. 399.

21. Selected Letters of Robert Frost, ed. Lawrance Thompson (New York: Holt, Rinehart and Winston, 1964), p. 552.

22. Introduction to King Jasper, Lathem and Thompson, p. 347. 
declared that "genius, all over the world, stands hand in hand, and one shock of recognition runs the whole circle round". ${ }^{23}$

Duke University

Victor Strandberg

23. Melville's assertion - from which Edmund Wilson derived the title of his eminent book of criticism - occurs near the end of "Hawthorne and His Mosses" (Norton Critical Edition of Moby-Dick, p. 547). 